\title{
Investigation of spectral properties of different Quaternary paleosols and parent materials
}

\author{
József SZEBERÉNYI ${ }^{1}$, Alzbeta MEDVED'OV Á², Pavel ROSTINSKY ${ }^{3}$, \\ Gabriella BARTA ${ }^{4}$, Ágnes NOVOTHNY ${ }^{4}$, DiánA CSONKA ${ }^{4}$, István VICZIÁN ${ }^{1}$, \\ ERzsébet HORV ÁTH ${ }^{4}$ and TAMÁs VÉGH ${ }^{4}$
}

\begin{abstract}
Diffuse Reflectance Spectroscopy (DRS) is a rapid, relatively new method in Quaternary research to analyse sediments and paleosols. This method takes into account clay mineral content, amount of Fe-bearing minerals and grain size composition of samples, simultaneously. Different Quaternary sediment samples were chosen for characterization and comparison their reflectance curves to detect the essential spectral properties of different paleosols and parent materials. Samples of different sediment types and paleosol variants were investigated from a loess-paleosol sequence from Malá nad Hronom (Slovakia) and from a fluvial-aeolian sediment complex from Pilismarót (Hungary). Five investigated curve sections were separated as the best indicators of reflectance properties of DRS curves. Spectral properties of samples were compared by using the length of investigated curve sections. This investigation showed quantifiable differences between the units of Pleistocene sediment successions, based on the reflectance properties. The influence of pedogenic processes was properly detectable. Significant discrepancies were observed between reflectance curves of well-developed paleosols and parent material samples in the visible and near-infrared range. Differences between the weak developed paleosol layers and their parent materials were only observed in the visible range. Fine sand, sandy silt and loess materials could be separated from each other based on the intensity of entire reflectance curves.
\end{abstract}

Keywords: diffuse reflectance spectroscopy, Pleistocene, loess, aeolian, alluvial, paleosol

\section{Introduction and research background}

The investigation of Quaternary sediments, such as loess-paleosol sequences, helps to reveal Pleistocene climate and environmental changes (MARKović, S.B. et al. 2011, 2015; Újvári, G. et al. 2014; Horváth, E. and BradÁK, B. 2014; VARGA, G. 2015; VARGA, G. et al. 2019). Besides the most commonly used proxies (e.g. grain size, magnetic susceptibility, carbonate content), applications of diffuse reflectance spectroscopy (DRS) method have become more widespread in this field (Buggle, B. et al. 2014; Krauss, L. et al. 2016;
Vlaminck, S. et al. 2016; ZeEden, C. et al. 2018; Wu, Y. et al. 2018). The method allows measurements in a rapid, non-destructive way and does not require complicated sample preparation. The visible and near-infrared (VIS-NIR) spectra allow simultaneous investigations of various parameters.

Reflectance spectra of fine-grained minerals showed specific properties, which were observed for the first time by Whiте, W.B. and Keester, K.L. (1966), and Adams, J.B. and Filice, A.L. (1967). Diffuse reflected light contains spectral information concerning the physical and chemical composition of the il-

\footnotetext{
${ }^{1}$ Geographical Institute, Research Centre for Astronomy and Earth Sciences. H-1112 Budapest, Budaörsi út 45. Hungary. Corresponding author's e-mail: szeberenyi.jozsef@csfk.mta.hu

${ }^{2}$ University of Matej Bel Faculty of Natural Science, Banská Bystrica, Tajovského 40, 974 01, Slovak Republic.

${ }^{3}$ Institute of Geonics AS CR, v.v.i., Ostrava-Poruba, Studentska 1768, 708 00, Czech Republic.

${ }^{4}$ Eötvös Loránd University, Institute of Geography and Earth Sciences, Department of Physical Geography, Pázmány Péter sétány 1/c, H-1117 Budapest, Hungary.
} 
luminated sample (BAumgardner, M.F. et al. 1985). DRS detects the electronic transitions of atoms in the visible spectrum (VIS), while the vibration deriving from the stretching and bonding of molecules and from the alterations of the bond angle is obtained in the near-infrared (NIR) range (SHEPHERD, K.D. and WALsh, M.G. 2002). The instrumental colour determination eliminates the subjectivity of the Munsell colour scale (Post, D. et al. 1993); therefore, the different sequences will be comparable. Lithostratigraphic subdivision of sediment series can be achieved by using the so-called colourimetric indices. Different indices were calculated to interpret diffuse reflectance spectra (VIS range) of Quaternary sediments (especially concerning loess-paleosol sequences). These were different colourimetric indices or Hematite/ Goethite (H/G) ratios.

Brightness values were calculated from the visible band primarily to identify the carbonate content of marine sediments (BALSAM, W.L. et al. 1999). This proxy is equivalent to Lightness (GODDARD, E.N. et al. 1948) and greyscale (Herbert, T.D. and Fischer, A.G. 1986). Ji, J.F. et al. (2001) used brightness as colourimetric index for investigation of loess-paleosol sequences for the first time. A strong relationship was observed between brightness and magnetic susceptibility (kappa low field, ${ }_{K} \mathrm{LF}$ ) values, similarly to lightness (Zhou, L.P. and Shackleton, N.J. 1998; WANG, Q. et al. 2016) and greyscale (Porter, S. 2000) proxies. JI, J.F. et al. (2001) draws attention to the modifying effect of non-magnetic light and dark minerals, which may change the values of the colourimetric index and thus the strength of the correlation.

The redness index (RI) was calculated from the red band of DRS curve for the first time by ZHANG, Y.G. et al. (2007) to identify the colourimetric parameters of marine sediments of South China Sea and were connected to hematite and goethite content - following the main assumption suggested by BARrón, V. and Torrent, J. (1986). RI used to replace the RR (Redness Rating: calculated from Munsell colour chart) values (Buntley, G. and Westin, F. 1965) and $\mathrm{RI}_{\mathrm{LAB}}$ (Redness Index: calculated from CIE colour system; CIE 1978) values (e.g. BARrón, V. and Torrent, J. 1986; Viscarra Rossel, R.A. et al. 2006). RI is a widely used colourimetric index for investigation of loess-paleosol sequences (e.g. Guo, Z.T. et al. 2009; Sun, Y. et al. 2011; Buggle, B. et al. 2014). RI and ${ }_{K} L F$ values are in strong positive correlation (e.g. BugGLE, B. et al. 2014), but it is always essential to take into account the possible colour-modifying effects of the organic matter and carbonate content (Sun, Y. et al. 2011).

Goethite and hematite can be transformed into each other due to changing climatic conditions (Schwertmann, U. 1971). Scheinost, A.C. et al. (1998) calculated the so-called $H / G$ ratio based on the relevant sections of the DRS curve to detect the transformation. Hematite and goethite both have a vital role during the investigation of loess-paleosol sequences. Torrent, J. et al. (2007) improved the method for the study of loess-paleosol sequences of the Chinese Loess Plateau: hematite concentration showed a strong positive correlation with the values of frequencydependent magnetic susceptibility. Based on previous investigations (e.g. BALSAM, W.L. et al. 2004; VIDIC, N.A. et al. 2004) it was stated, that $\mathrm{H} / \mathrm{G}$ ratios are good paleoclimatic indicators - although specific questions are still open. H/G ratios do not show good correlation with ${ }_{\mathrm{K}} \mathrm{LF}$ values in each case (WANG, Q. et al. 2016), and hematite concentrations measured in a given range can be influenced by the presence of other materials (Liv, Q. et al. 2011).

Particular indices were calculated from DRS measurement data during the investigation of terrestrial sediments. These indices were added to multiproxy investigations and thus were used for more detailed description of profiles (ZHANG, Y.G. et al. 2007; KRAUss, L. et al. 2016; VLAMINCK, S. et al. 2016; ZEEDEN, C. et al. 2018) in order to reveal the intensity of pedogenesis (ВÁвEK, O. et al. 2011) and to reconstruct paleoclimate and paleoenvironment (Guo, Z.T. et al. 2009; Sun, Y. et al. 2011; Buggle, B. et al. 2014; WANG, Q. et al. 2016; Wu, Y. et al. 2018). 
Compound loess-paleosol sequences can be divided into different groups and interpreted as stratigraphic units of loess-paleosol successions by applying cluster analysis of DRS data. This is a new approach introduced in loess research by SzEBERÉNYI, J. et al. (2020, in press). Three important frequency ranges were identified, which are the most critical sections in the entire measurement range: (1) The reflectance intensity of a sample in the 400-825 nm frequency range was modified by hematite and goethite, illite, montmorillonite, muscovite and calcite. (2) Mainly montmorillonite and kaolinite played important roles in modifying the reflectance curve of a sample in the 900-1,100 nm frequency range. Fe-bearing minerals had only a minimal influence in this range. (3) The reflectance curve was only modified by montmorillonite in the $1,445-1,460 \mathrm{~nm}$ range. This approach proved that the reflectance properties of DRS curves are suitable for the differentiation of paleosols and their parent materials (e.g. loess). Although the question is raised, whether it is easier to identify curve sections, that indicate apparent differences between reflectance properties of paleosol and parent material samples.

As a continuation of our previous studies, this paper reveals the relationship between the DRS curves of paleosols and their parent material. The basis of recent research was the most important curve sections (between 400-1,460 nm wavelength range) of the entire measurement range. The goal of the actual study was to quantify the significant differences between the original reflectance curves of paleosols and their parent materials in the case of different Quaternary sediment successions.

\section{Site and sampling}

Loess, alluvial sandy aleurite and fluvial sand are widespread Pleistocene sediment types in the Carpathian Basin. They generally serve as parent materials for soil development. Two successions were investi- gated in the present study: a loess-paleosol sequence and a fluvial-aeolian sediment complex. The loess-paleosol sequence is located in the vicinity of Malá nad Hronom, Slovakia (130-155 m a.s.1.; N47 $49^{\prime} 46.0^{\prime \prime}$ and E19 $\left.02^{\prime} 33.6^{\prime \prime}\right)$. The abandoned brickyard is found in the western side of a dissected fluvial terrace of the Hron river, which is a tributary of the Danube river. The fluvialaeolian sediment complex is located in the region of Pilismarót, Hungary (103-107 m a.s.l.; N47 $48^{\prime} 6.44^{\prime \prime}$ and E18 $\left.52^{\prime} 31.45^{\prime \prime}\right)$. The abandoned gravel mine is on the lowest terrace of the Danube river (Figure 1).

One profile $(\mathrm{MNH})$ was excavated in the loess-paleosol sequence at Malá nad Hronom (Figure 2). Seven different stratigraphical units were identified, which can be summarized from the top to the bottom as follows: - Unit L1 (0-160 cm): Greyish yellow, wellcemented, homogeneous, non-layered loess with low fine sand content. 16 samples were measured from this unit.

- Unit T1 (160-220 cm): A light brownish intermediate layer was detected between L1 and P1. The silty material was loose, nonlayered, without any sediment structure.

- Unit P1 (220-320 cm): Light reddishbrown, weakly developed paleosol with granular ped structure. 8 samples were taken from this layer.

- Unit T2 (320-390 cm): A yellowish/light brownish intermediate layer was observed between the two paleosols. The transition zone consisted of loose, non-layered silty material.

- Unit P2 (390-490 cm): The paleosol of Unit P2 was characterized by two pedogenic horizons. The uppermost pedogenic horizon (390-420 cm) was clayey with dark brown colour and was described by welldeveloped blocky structure. A 50-60 cm thick, reddish-brown, weakly developed soil horizon was observed in the lower part of this unit (between $420-490 \mathrm{~cm}$ ). 8 samples were measured from P2 paleosol unit. - Unit LCa (490-520 cm): Well-compacted carbonate accumulation zone of the P2 paleosol. 


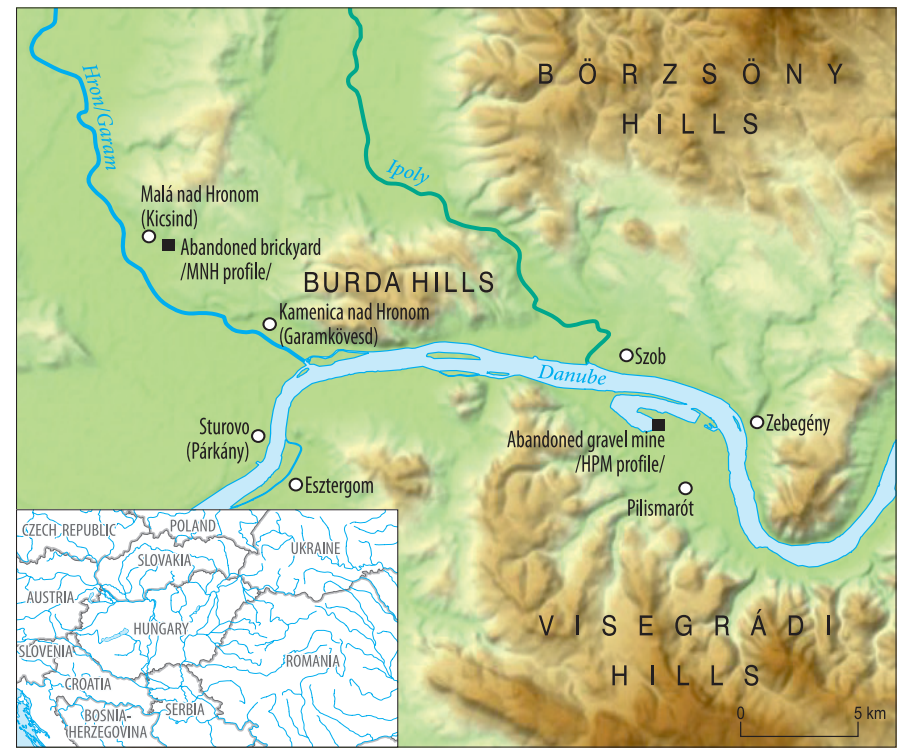

Fig. 1. The geographical location of the investigated successions
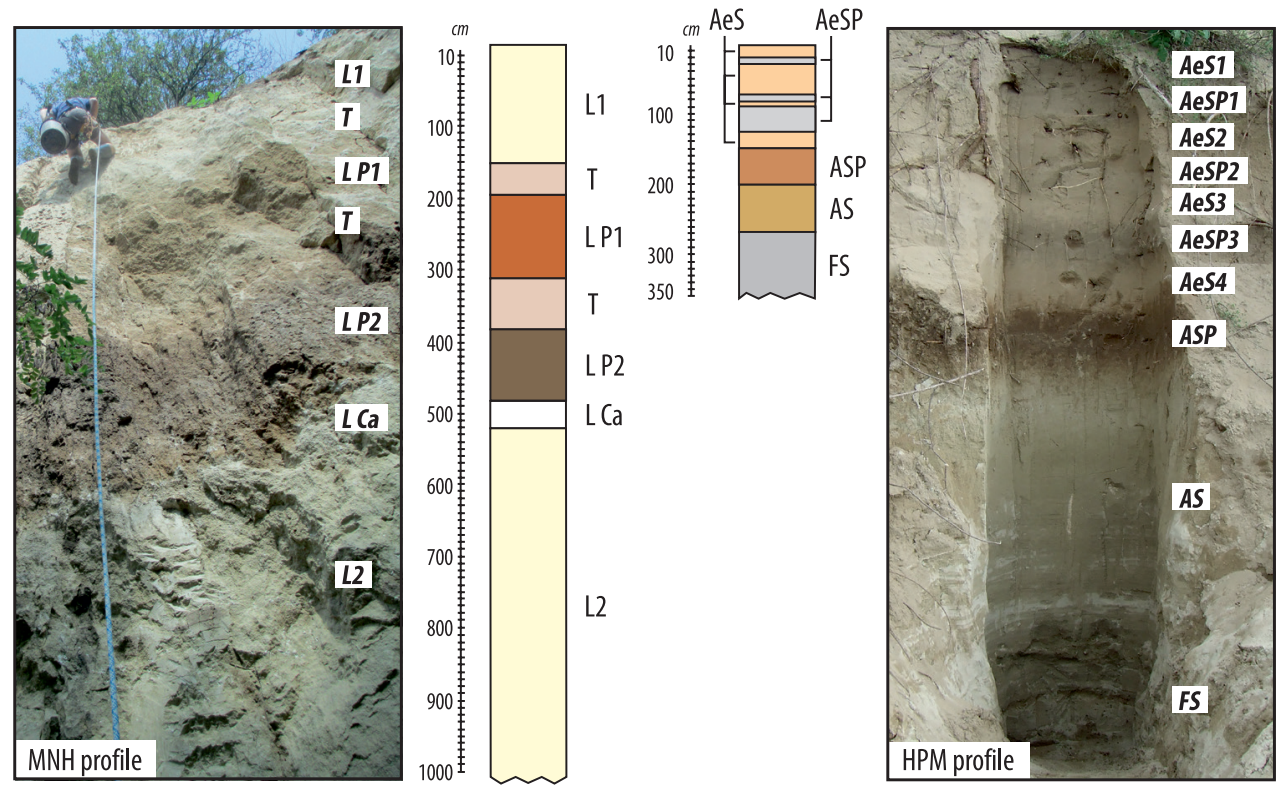

Fig. 2. The investigated successions. L1, L2 = loess units; T1, T2 = intermediate layers; LP1, LP2 = paleosol layers; LCa = carbonate accumulation horizon; AeS1, AeS2, AeS3, AeS4 = aeolian sand layers; AeSP1, AeSP2, AeSP3 = paleosol horizons in aeolian sand; ASP = paleosol layer on alluvial sand unit; AS = alluvial sand unit; FS = fluvial sand unit. 
- Unit L2 (520-1,010 cm): The base of the sequence was a grey/greyish-yellow loess layer with at least $5 \mathrm{~m}$ thickness. This unit was porous, loose, non-layered, and homogeneous. Secondary carbonates were observed in the field. 36 L2 samples were taken for reflectance measurements.

One profile (HPM) was investigated in the fluvial-aeolian sediment complex at Pilismarót (see Figure 2). Five different stratigraphical units were identified, which were described from the top to the bottom as follows:

- Units AeS and AeSP (0-150 cm): An aeolian sand-paleosol complex was identified in the upper part of the sequence, which consisted of several layers. 4 light grey/ greyish-yellow, loose, homogeneous/ finely laminated fine aeolian sand layers (AeS) were detected between 0-20, 30-70, 80-90 and 120-150 cm depth. 9 samples were taken from parent material unit. 3 grey/greyish yellow coloured, weakly developed paleosol horizons (AeSP) with granular ped structure were observed between 20-30, 70-80 and 90-120 cm depth. 6 paleosol samples were measured from these horizons.

- Unit ASP (150-210 cm): A well-developed, clayey reddish-brown paleosol was identified in the middle of the sequence. The angular blocky ped structure included clay coatings and slick and slide phenomenon. 6 ASP samples were taken for measurements.

- Unit AS (210-280 cm): Fine-grained alluvial silty sand was detected as parent material of the ASP paleosol. This stratum was divided into different sublayers. The lowermost part of the layer was a $30 \mathrm{~cm}$ thick, fine laminated, grey coloured material with limonite dots. This part was overlain by a $40 \mathrm{~cm}$ thick yellowish-grey, homogenous, non-laminated sandy silt layer. 5 samples were measured from this layer. - Unit FS (280-360 cm): The base of the sequence was thick cross-bedded fluvial sand, which was grey, coarse-grained and contained fine pebbles and a thin gravel layer $(320-330 \mathrm{~cm})$.

\section{Methods}

The samples were air-dried and dry sieved trough a $250 \mu \mathrm{m}$ sieve, as preparation for reflectance measurements. The samples were proceeded with a Shimadzu UV-3600 spectrophotometer (Geographical Institute, Research Centre for Astronomy and Earth Sciences, Hungary) in Hellma Precision cells made of quartz SUPRASIL 300 and were optimized in the UV-VIS-NIR range (Figure 3).

The test samples were very noisy in the most extended wavelength section of the NIR range (2,000-2,500 nm); therefore, the samples of the present study were measured only between 240 and 2,000 nm. Scan speed was $0.54 \mathrm{sec}$ in $1 \mathrm{~nm}$ sampling interval. Optimal slit with was $20 \mathrm{~nm}$. Change in the wavelength of the detector $(\mathrm{Pbs} / \mathrm{Pm})$ was at $830 \mathrm{~nm}$, while light source (D2 deuterium/W1 halogen) change wavelength was at $310 \mathrm{~nm}$ and grating change wavelength was at 710 nm (green points on Figure 3), which were identified as uncertain measurement points. The diffuse reflectance was recorded by the LISR-3100 integrating sphere. Each sample spectra were corrected for background absorption by the division of the reflectance spectrum of standardized white $\mathrm{BaSO}_{4}$ panel.

The reflectance intensity was expressed in percentage $(\mathrm{R} \%)$ of the measurement range (240-2,000 nm). One DRS curve contains 1,760 data points (given in $\mathrm{R} \%$ ), which refer to the quantity of light reflected per $\mathrm{nm}$. The entire reflectance spectra of samples could be displayed on a diagram (blue curve on Figure 3). All paleosol and parent material samples were analysed using the intensity of their entire reflectance curves, which helps to recognize the fundamental differences in their reflectance properties.

Several curve sections were identified to characterize and quantify the reflectance properties of samples. The most variable wavelength ranges (between 400-825, 901,000 and 1,445-1,460 $\mathrm{nm}$ ) were separated from the full measurement range based on our earlier results (SzEBERÉNYI, J. et al. 2020, in press). Within these wavelength ranges five 


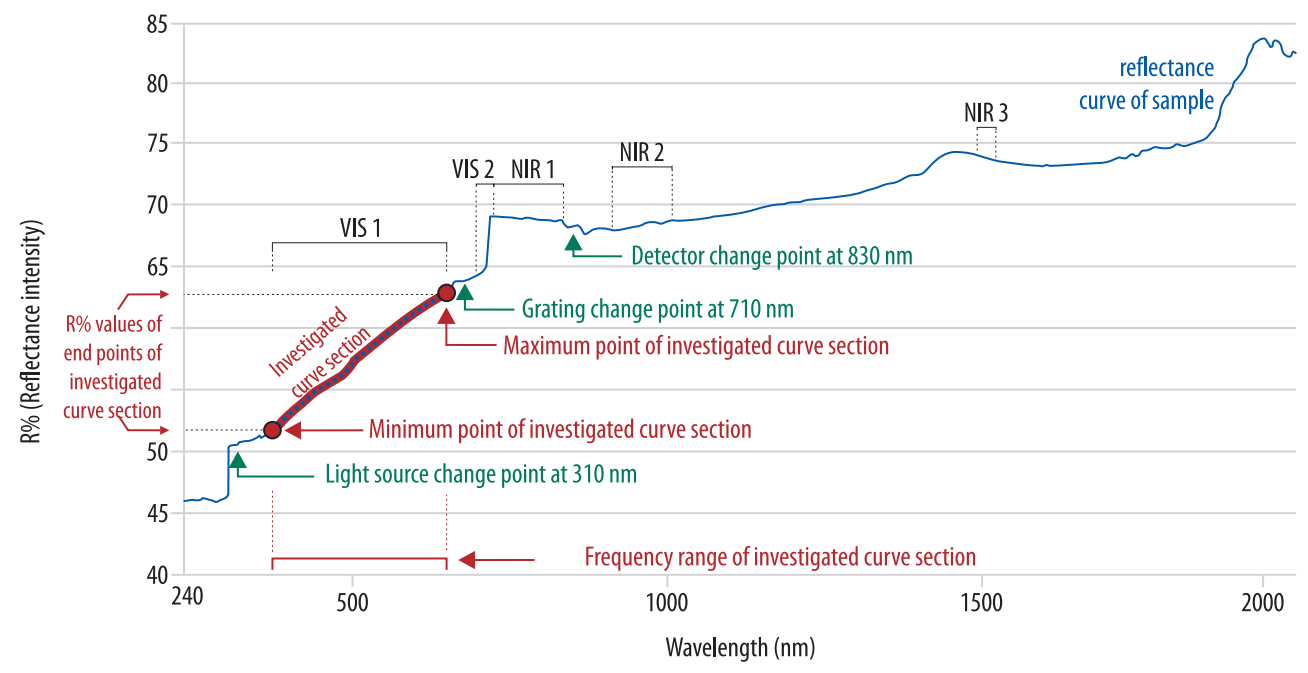

Fig. 3. The most important parameters of the method are shown on the entire reflectance spectra of one representative sample

investigated curve sections were identified for this study that generally rises or drops monotonically toward longer wavelengths (1), and not contains any uncertain measurement points such as detector, grating and light source change points (2). Two frequency ranges were identified in the visible band (VIS 1 and VIS 2) and three in the nearinfrared range (NIR 1, NIR 2 and NIR 3). These investigated frequency ranges are the best indicators of reflectance properties of the DRS curves (see Table 1 and Figure 3). The five investigated sections of reflectance curves of paleosol and parent material samples were compared to each other in this study.

The investigated curve sections could be characterized by an increase or a decrease of $\mathrm{R} \%$ value in the investigated frequency range. The minimum and maximum $\mathrm{R} \%$ values could be measured at the endpoints of the investigated curve section (red on Figure 3 ). $\Delta \mathrm{R} \%$ gives the difference of maximum and minimum $\mathrm{R} \%$ values in the investigated frequency range. If $\mathrm{R} \%$ value increased in the investigated frequency range, the $\Delta \mathrm{R} \%$ value is positive. In contrast, a negative $\Delta R \%$ value signifies a decreasing tendency between the endpoints of the investigated curve section. Steeper curve section could be characterized by higher $\Delta \mathrm{R} \%$ value.

\section{Results}

In general, the $\mathrm{R} \%$ values showed an increasing tendency between 240 and 2,000 $\mathrm{nm}$ wavelength range. Minimum $\mathrm{R} \%$ values were detected between 290-300 nm, whereas the maximum values were present between 1,950-1,955 nm. The sediment types could be characterized by different amplitudes of their reflectance curve. The most considerable difference (min: 47.6R\%, max: $87.2 \mathrm{R} \%$ ) was observed for loess, while the smallest difference (min: $47.5 \mathrm{R} \%$, max: $76.4 \mathrm{R} \%$ ) was characteristic for aeolian sand (Figure 4, a). The intensities of DRS curves regarding paleosols were lower than those of their parent material in each case (Figure 4, b, c, d).

Curve sections of Unit L1 and L2 samples could be characterized by the highest $\Delta \mathrm{R} \%$ value in the VIS 1 range (Figure 5, a), concerning the samples of the loess-paleo- 
Table 1. Endpoints and uncertain points of investigated curve sections

\begin{tabular}{l|c|c|c|c|c|c|c|c}
\hline $\begin{array}{c}\text { Name of the } \\
\text { frequency range }\end{array}$ & $\begin{array}{c}\text { Light } \\
\text { source } \\
\text { change }\end{array}$ & VIS 1 & $\begin{array}{c}\text { Grating } \\
\text { change }\end{array}$ & VIS 2 & NIR 1 & $\begin{array}{c}\text { Detector } \\
\text { change }\end{array}$ & NIR 2 & NIR 3 \\
\hline $\begin{array}{l}\text { End points of } \\
\text { investigated fre- } \\
\text { quency range, nm }\end{array}$ & - & 400 & - & 715 & 725 & - & 900 & 1,445 \\
$\begin{array}{l}\text { Uncertain meas- } \\
\text { urement point, nm }\end{array}$ & 310 & - & 710 & - & - & 830 & - & - \\
\hline
\end{tabular}

sol sequence. Loess samples had the same values. The $\mathrm{R} \%$ values of samples increased by 10.1-11.5 per cent from the minimum to the maximum value. $\Delta \mathrm{R}$ values of curve sections of paleosols were smaller than those of their parent materials. The $\mathrm{R} \%$ value of P1 paleosol increased by 9.2-9.7 per cent between the endpoints of the curve section, whereas the P2 paleosol showed only 5.8-7.8 per cent increase. An opposite trend was observed in the case of the alluvial units $(\Delta R$ of AS: $5.8-6.6 \%$ and $\triangle \mathrm{R}$ of ASP: $6.2-9.7 \%)$, and there was no significant difference between aeolian samples ( $\Delta \mathrm{R}$ of AeS: $6.3-7.5 \%$ and $\Delta \mathrm{R}$ of AeSP: 6.8-7.0\%) (Figure 5, b, c).

The $\mathrm{R} \%$ values of paleosols had slightly higher $\Delta \mathrm{R} \%$ values in the VIS 2 range than their parent material (Figure 5, d, e, f). The most significant difference was observed for the samples of the loess-paleosol sequence $(\Delta \mathrm{R}$ of $\mathrm{L} 1$ and $\mathrm{L} 2: 3.6-4.5 \% ; \Delta \mathrm{R}$ of $\mathrm{P} 1$ : $4.5-4.8 \%$ and $\Delta \mathrm{R}$ of $\mathrm{P} 2: 5.2-5.7 \%)$.
$\mathrm{R} \%$ values of parent materials decreased in the NIR 1 range by $-0.9-0.6$ per cent $(\Delta R)$ for Loess, -1.3-1.1 per cent $(\Delta R)$ for $A S$ and -0.8-0.6 per cent $(\Delta \mathrm{R})$ for AeS (Figure $5, \mathrm{~g}, \mathrm{~h}, \mathrm{i})$. A slighter decrease $(\triangle R$ : $-0.8-0.5 \%)$ was characteristic for the weakly developed P1 paleosol, whereas the $\mathrm{R} \%$ value of the AeSP paleosol remained constant $(-0.6-0.1 \%)$ in relation to the parent materials of both units. The value of the well-developed paleosol of loess-paleosol sequence increased between the endpoints of NIR 1 curve section ( $\triangle \mathrm{R}$ of P2: $0.2-0.6 \%$ ). ASP paleosol layer could be divided into two parts (ASPa and b) in this frequency range. The $\mathrm{R} \%$ values of the middle part of alluvial paleosol increased ( $\triangle \mathrm{R}$ of ASPa: $0.1-0.5 \%$ ), whereas the lower and upper part of alluvial paleosol could be characterized by a decreasing tendency $(\triangle \mathrm{R}$ of $\mathrm{ASPb}:-0.2--0.7 \%)$ (Figure 5, g, i).

The $\mathrm{R} \%$ values of alluvial sandy aleurite decreased in the NIR 2, whereas loess and
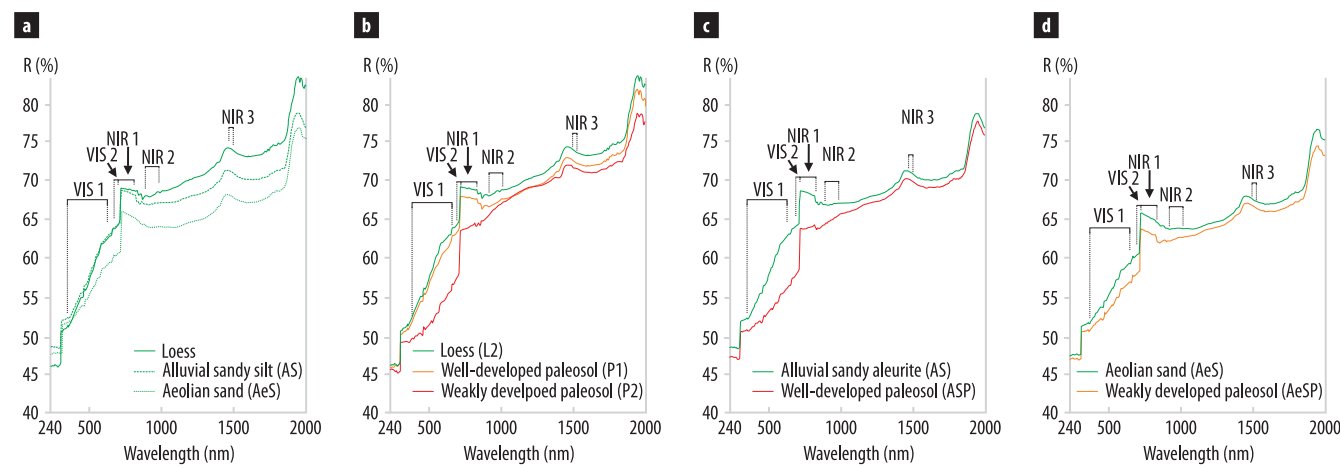

Fig. 4. Entire reflectance curves of samples 


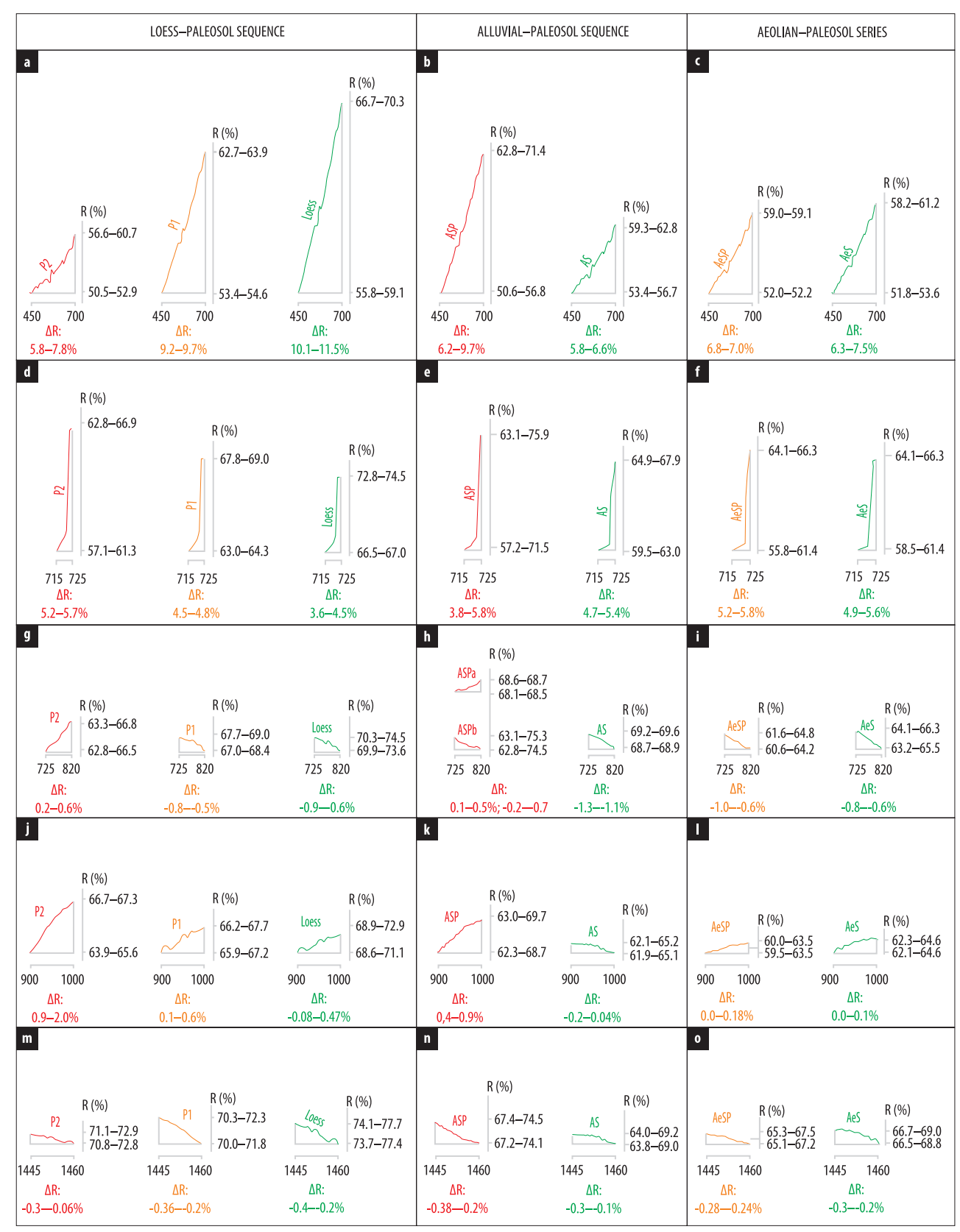

Fig. 5. Comparison of investigated curve sections in the investigated ranges

aeolian sand could be characterized by an increasing tendency. Only a slight difference was observed between the values of the weakly developed paleosols and their parent materials in the NIR 2 frequency range $(\Delta R$ of L1 and L2: $-0.08-0.47 \%$; $\triangle \mathrm{R}$ of P1: $0.1-0.6 \%$; 
$\triangle \mathrm{R}$ of AeS: $0.0-0.1 \%$ and AeSP: $0.00-0.18 \%$ ) (Figure 5, j, 1). Well-developed paleosols were characterized by steeper curve sections ( $\triangle \mathrm{R}$ of $\mathrm{P} 2$ : $0.9-2.0 \% ; \Delta \mathrm{R}$ of ASP: $0.4-0.9 \%$ ) (Figure 5, j, k).

In general, $\mathrm{R} \%$ values decreased concerning the NIR 3 frequency ranges. Minimal differences could be observed between loesspaleosol samples ( $\triangle \mathrm{R}$ of L1 and L2: $-0.4-$ $-0.2 \%, \mathrm{P} 1:-0.36--0.20 \%$, P2: $-0.30--0.06 \%)$, the alluvial-paleosol samples ( $\triangle \mathrm{R}$ of $\mathrm{AS}$ : $-0.3--0.1 \%$, ASP: $-0.38--0.20 \%$ ) and the aeolian sand-paleosol samples ( $\triangle \mathrm{R}$ of AeS: -0.3$-0.2 \%$, AeSP: $-0.28--0.24 \%$ ) (Figure 5, m, n, o).

\section{Discussion}

DRS measurements are useful for the differentiation between loess and sandy samples and for the recognition of possible differences between paleosols and their parent materials. Sediment types can be separated from each other, based on the mean intensity of the complete DRS curves. Aeolian sands can be differentiated from alluvial silty sands and loesses based on the visible and nearinfrared bands (especially between 950-2,000 $\mathrm{nm}$, see Figure 4, a). The entire DRS curves of paleosols were characterized by lower intensity than their parent materials. Besides the mineral components, the reflectance intensity was influenced by the grain size composition as well (Hunt, G.R. 1989; CLARK, R.N. 1999). DRS curves of parent materials (fine sand, sandy silt, loess) and well-developed paleosol samples were definitely modified by these factors (especially concerning the presence of higher clay fraction).

By the help of the five curve sections, it was possible to reveal and quantify the most important reflectance properties of DRS curves. The most prominent changes were present in the VIS 1, NIR 1 and NIR 2 frequency ranges, although certain tendencies appeared to be identifiable in the VIS 2 and NIR 3 frequency ranges too (Figure 6).

In general, significant differences could be shown between $\Delta R \%$ values of well-de- veloped paleosols (especially P2) and their parent materials. In contrast, only moderate or little differences were detected between weakly developed paleosols and their parent materials (see Figure 6). Changes of carbonate content, the formation of clay minerals and the transformation of Fe-bearing minerals were the reason for abovementioned phenomena, and those parameters are very important in relation to pedogenic processes. Generally, paleosols can be characterized by lower carbonate and goethite concentration, and higher hematite and clay mineral contents, which are all influenced by paleoclimatic and paleoenvironmental conditions. The involved minerals were very well detected components using diffuse reflectance spectroscopy. DRS measurements are sensitive to the changes of the amount of Fe-bearing minerals (TorRent, J. et al. 1983; Hunt, G.R. 1989; Deaton, B.C. and BALSAM, W.L. 1991) and the carbonate content (BALSAM, W.L. et al. 1999) of the sediments in the visible band; and to the changes of clay mineral content (CLARK, R.N. 1999) in the near-infrared range.

The investigated weakly developed paleosols (especially P1) differentiated from their parent materials only in the visible range. On the contrary, significant differences were detected between well-developed paleosols and their parent materials both in the visible and near-infrared bands. The changes of carbonate content and the amount of Fe-bearing minerals is possibly connected to the earlier stage of pedogenic development, whereas the accumulation of clay minerals is related to longer time periods and/or to the presence of stronger pedogenic processes.

Furthermore, another interesting observation was that the reflectance properties of different sediment types (fine sand, sandy silt, loess) were comparable to each other, mainly in the visible range. AS and AeS samples could be characterized by the same values ( $\Delta \mathrm{R}$ in VIS 1: $5.8-7.5 \%$; $\Delta \mathrm{R}$ in VIS 2: 4.7-5.6\%), whereas L1 and L2 samples had higher values ( $\triangle \mathrm{R}: 10.1-11.5 \%)$ in the VIS 1 and lower values ( $\triangle \mathrm{R}: 3.6-4.5 \%$ ) in the VIS 2 band. 

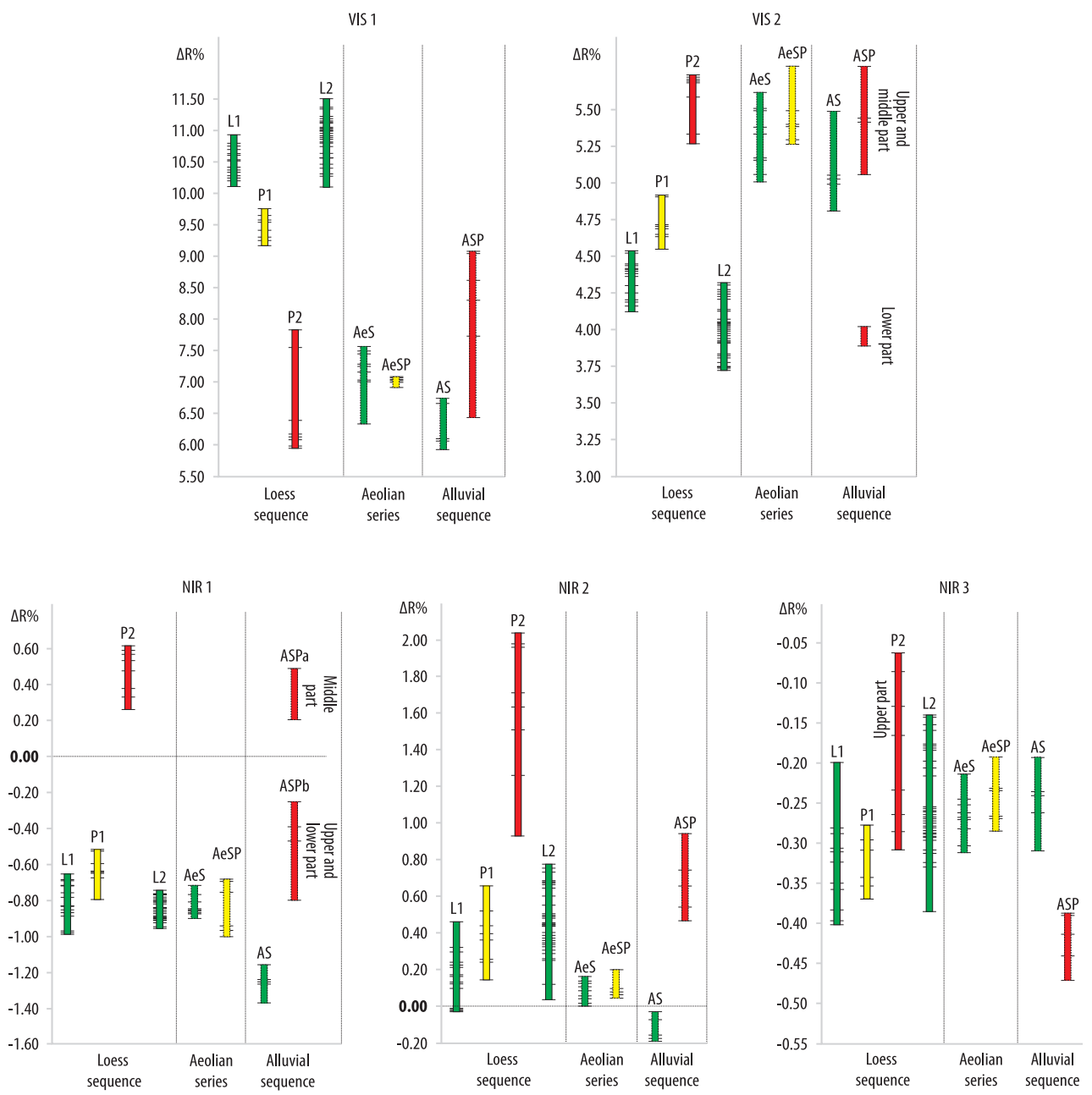

Fig. 6. Changes of $\Delta \mathrm{R} \%$ of curve sections in the five investigated frequency ranges

The 715-820 nm were substantial frequency ranges in our study, based on which the alluvial paleosol layer could be divided into three horizons. I can be seen on Figure 6 that (1) the lower part of ASP layer was characterized by significantly lower $\Delta \mathrm{R} \%$ values in the VIS 2 than the other samples of this layer, and (2) the middle part of ASP had higher $\Delta \mathrm{R} \%$ values in the NIR 1 range, than their uppermost and lowermost horizons. The spectral features of illite and hematite can be traced in these frequency ranges, there- fore, in this case, these minerals played the most important role during the pedogenesis, based on our earlier study (SZEBERÉNYI, J. et al. 2020, in press).

Generally, the alterations of curve sections are established mainly by different mineral groups and not by the individual minerals, except in the 1,445-1,460 $\mathrm{nm}$ frequency range based on our earlier results (SzEBERÉNYI, J. et al. 2020, in press). This narrow range is modified only by montmorillonite. This fact can be regarded as very important as signifi- 
cant discrepancies were observed between the reflectance curves of two well-developed paleosols in the NIR 3 range. Curve section of P2 paleosol samples (especially the upper part of this layer) were steeper than those of their parent materials, which could be explained by montmorillonite enrichment. On the contrary, the curve section of ASP paleosol layer could be characterized by lower $\Delta \mathrm{R} \%$ values than the alluvial sandy aleurite samples (Figure 6). Probably the ASP paleosol can be characterized by low montmorillonite and high illite content (especially the middle part of this layer; Figure 3, NIR 1). Illite forms in potassium-rich soils by the transformation of high-temperature micas, usually muscovite (e.g. JACKsON, M.L. 1964; Ellis, S. and Mellor, A. 1992; Righi, D. and Meunier, A. 1995). Reinbach, H. and Rich, C. (1975) indicated that the process of smectite/ illite transformation is intimately associated with silica-poor and potassium-rich environment. Presumably, these processes are standing in the background of pedogenesis of ASP paleosol.

\section{Conclusions}

Reflectance measurements of samples in different Quaternary sediment successions were investigated and compared in order to reveal and quantify the most important reflectance properties. We found that (1) the assessment of DRS curves from Quaternary sediment successions indicated the presence and intensity of pedogenic processes; (2) the reflectance properties of DRS curves could be identified by both the mean intensity of the whole reflectance curve and the length of the investigated curve sections. Therefore, essential conclusions can be drawn from the investigation of curve sections regarding the intensity of pedogenic processes. The detectable differences of the length of investigated curve sections can be quantified by $\Delta \mathrm{R} \%$.

The method of this study took into account the changes of the mineral composition and the alterations of grain size at the same time. Reflectance properties of DRS curves were suitable for the recognition of the tracers of pedogenic processes in the case of Quaternary terrestrial successions, although some unresolved questions remained. Further investigations are needed to determine the degree of change, which influences the mineral and grain size compositions. It is an exciting topic to find the mineral (or minerals) that affect the alterations of the investigated curve sections using XRD measurements.

Acknowledgements: This research was carried out within the framework of the International Visegrad Fund (project Number 11410020). The paper was also supported by a long-term conceptual development subvention available to research organizations RVO: 68145535 from the Institute of Geonics AS CR, by the Slovak Research and Development Agency under contract No. APVV-0625-11 (project "A new synthesis of the Western Carpathians landform evolution - preparation of the database for testing of key hypotheses". The research was also supported by NKFI K119366, and NKFI K 100180.

\section{REFERENCES}

Adams, J.B. and Filice, A.L. 1967. Spectral reflectance of 0.4 to 2.0 microns of silicate rocks powders. Journal of Geophysical Research 72. 5705-5715.

Bábek, O., Chlachula, J. and Grygar, T.M. 2011. Nonmagnetic indicators of pedogenesis related to loess magnetic enhancement and depletion: Examples from the Czech Republic and southern Siberia. Quaternary Science Reviews 30. 967-979.

Balsam, W.L., Deaton, B.C. and Damuth, J.E. 1999. Evaluating optical lightness as a proxy for carbonate content in marine sediment cores. Marine Geology 161. 141-153.

Balsam, W.L., Ji, J. and Jun Chen, J. 2004. Climatic interpretation of the Luochuan and Lingtai loess sections, China, based on changing iron oxide mineralogy and magnetic susceptibility. Earth and Planetary Science Letters 223. 335-348.

Barrón, V. and Torrent, J. 1986. Use of the KubelkaMunk theory to study the influence of iron oxides on soil colour. Journal of Soil Science 37. 499-510.

Baumgardner, M.F., Silva, L.F., Biehl, L.L. and StONER, R. 1985. Reflectance properties of soils. Advances in Agronomy 38. 1-44.

Buggle, B., Hambach, U., Müller, K., Zöller, L., Marković, S. and Glaser, B. 2014. Iron miner- 
alogical proxies and Quaternary climate change in SE-European loess-paleosol sequences. Catena 117. 4-22.

Buntley, G. and Westin, F. 1965. A comparative study of developmental color in a Chestnut-ChernozemBrunizem soil climosequence. Soil Science of America Proceedings 29. 579-582.

CLARK, R.N. 1999. Spectroscopy of rocks and minerals, and principles of spectroscopy. In Remote Sensing for the Earth Sciences: Manual of Remote Sensing. Ed.: Rencz, N., New York, John Wiley and Sons, 3-52.

Commission Internationale de l'Eclairage (CIE) 1978. Recommendations on Uniform Color Spaces, Color Differences, and Psychometric Colour Terms. Paris, Calorimetry CIE, Suppl. no. 2 to Publication no. 15.

Deaton, B.C. and Balsam, W.L. 1991. Visible spectroscopy - a rapid method for determining hematite and goethite concentration in geological materials. Journal of Sedimentary Petrology 61. 628-632.

Ellis, S. and Mellor, A. 1992. Soils and Environment. London, Routledge.

Goddard, E.N., Trask, P.D., De Ford, R.K., Rove, O.N., Singewald, J.T. and Overbeck, R.M. 1948. Rock color chart. Boulder, Colorado, Geological Society of America.

Guo, Z.T., Berger, A., Yin, Q.Z. and QIN, L. 2009. Strong asymmetry of hemispheric climates during MIS-13 inferred from correlating China loess and Antarctica ice records. Climate of the Past 5. 21-31.

Herbert, T.D. and Fischer, A.G. 1986. Milankovitch climatic origin of mid-Cretaceous black shale rhythms in central Italy. Nature 321. 739-743.

Horváth, E. and Bradák, B. 2014. Sárgaföld, losz, lösz: short historical overview of loess research and lithostratigraphy in Hungary. Quaternary International 319. (1): 1-10.

HunT, G.R. 1989. Spectroscopic properties of rocks and minerals. In Practical Handbook of Physical Properties of Rocks and Minerals. Ed.: CARMiChael, R.S., Boca Raton FL, CRC Press, 597-669.

JACKSON, M.L. 1964. Chemical composition of the soil. In Chemistry of the Soil. Ed.: BeAR, F.E., New York, Reinhold, 71-141.

Ji, J.F., Balsam, W.L. and Chen, J. 2001. Mineralogic and climatic interpretations of the Luochuan loess section (China) based on diffuse reflectance spectrophotometry. Quaternary Research 56. 23-30.

Krauss, L., Zens, J., Zeeden, C., Schulte, P., Eckmeier, E. and LeнmкunL, F. 2016. A multi-proxy analysis of two loess-paleosol sequences in the Northern Harz Foreland, Germany. Palaeogeography, Palaeoclimatology, Palaeoecology 461. 401-417.

Liu, Q., Torrent, J., Barrón, V., Duan, Z.Q. and Bloemendal, J. 2011. Quantification of hematite from the visible diffuse reflectance spectrum: effects of aluminium substitution and grain morphology. Clay Minerals 46. 137-147.
Marković, S.B., Hambach, U., Stevens, T., Kukla, G.J., Heller, F., McCoy, W.D., Oches, E.A., Buggle, B. and ZöLLER, L. 2011. The last million years recorded at the Stari Slankamen (Northern Serbia) loesspaleosol sequence: revised chronostratigraphy and long-term environmental trends. Quaternary Science Reviews 30. 1142-1154.

Marković, S.B., Stevens, T., Kukla, G.J., Нambach, U., Fitzsimmons, K.E., Gibbard, P., Buggle, B., Zech, M., Guo, Z., Hao, Q., Wu, H., O'Hara Dhand, K., Smalley, I.J., Újvári, G., SÜmegi, P., Timar-Gabor, A., Veres, D., Sirocko, F., Vasiljević, D.A., Jary, Z., Svensson, A., Jović, V., LehmKuhl, F., Kovács, J. and SvirčEv, Z. 2015. Danube loess stratigraphy Towards a Pan-European loess stratigraphic model. Earth Science Reviews 148. 228-258.

Porter, S. 2000. High-resolution paleoclimatic information from the Chinese eolian sediments based on grayscale intensity profiles. Quaternary Research 53. 70-77.

Post, D., Bryant. R.B., Batchily, A.K. and Huete, A.R. 1993. Correlations between field and laboratory measurements of soil color. In Soil Color. Eds.: Bigham, J.R. and Ciolkosz, E.J., Spec. Publ. 31. Madison WI, SSSA, 35-50.

Reichenbach, H. and Rich, C.I. 1975. Fine-grained micas in soils. In Soil Components. Vol 2: Inorganic Components. Ed.: Gieseking, J.E., Berlin, Springer Verlag, 60-86.

Righi, D. and Meunier, A. 1995. Origin of clays by rock weathering and soil formation. In Origin and Mineralogy of Clays: Clays and the Environment. Ed.: Velde, B., Heidelberg, Springer Verlag, 43-161.

Scheinost, A.C., Chavernas, A., Barron, V. and Torrent, J. 1998. Use and limitations of secondderivative diffuse reflectance spectroscopy in the visible to near-infrared range to identify and quantify Fe oxide minerals in soils. Clays and Clay Minerals 46. 528-536.

Schwertmann, U. 1971. Transformation of hematite to goethite in soils. Nature 232. 624-625.

SHEPHERD, K.D. and WALSH, M.G. 2002. Development of reflectance spectral libraries for characterization of soil properties. Soil Science Society of America Journal 66. 988-998.

Sun, Y., He, L., Liang, L. and AN, Z. 2011. Changing colour of Chinese loess: Geochemical constraint and paleoclimatic significance. Journal of Asian Earth Sciences 40. 1131-1138.

Szeberényi, J., Kovács, J., Bradák, B., Barta, G., Csonka, D., Medveňová, A., Roštínský, P., Kiss, K. and VARGA, G. 2020. Experiencing new perspectives in the application of reflectance spectroscopy in loess research. Quaternary International (in press).

Torrent, J., LiU, Q., Bloemendal, J. and Barrón, V. 2007. Magnetic enhancement and iron oxides in the Upper Luochuan loess-paleosol sequence, Chinese Loess Plateau. Soil Science Society of America Journal 71. 1570-1578. 
Torrent, J., Schwertmann, U., Fechter, H. and Alférez, F. 1983. Quantitative relationships between color and hematite content. Soil Science 136. (6): 354-358.

Újvári, G., VArga, A., Raucsik, B. and Kovács, J. 2014. The Paks loess-paleosol sequence: A record of chemical weathering and provenance for the last $800 \mathrm{ka}$ in the mid-Carpathian Basin. Quaternary International 319. 22-37.

VARGA, G. 2015. Changing nature of pleistocene interglacials - is it recorded by paleosoils in Hungary (Central Europe)? Hungarian Geographical Bulletin 64. (4): 317-326.

VARGA, G., ÚJvÁrI, G. and KovÁcs, J. 2019. Interpretation of sedimentary (sub)populations extracted from grain size distributions of Central European loesspaleosol series. Quaternary International 502. Part A, 60-70.

Vidic, N.A., Singer, M.J. and Verosub, K.L. 2004. Duration dependence of magnetic susceptibility enhancement in the Chinese loess-paleosols of the past 620 ky. Palaeogeograpaphy, Palaeoclimatology, Palaeoecology 211. 271-288.

Viscarra Rossel, R.A., Minasny, B., Roudier, P. and McBartney, A.B. 2006. Colour space models for soil science. Geoderma 133. 320-337.

Vlaminck, S., Kehl, M., Lauer, T., Shahriari, A., Sharifi, J., Eckmeier, E., Lehndorff, E., Khormali, F. and Frechen, M. 2016. Loess-soil sequence at Toshan (Northern Iran): Insights into late Pleistocene climate change. Quaternary International 399. 122-135.
Wang, Q., Song, Y., Zhao, Z. and Li, J. 2016. Colour characteristics of Chinese loess and its paleoclimatic significance during the last glacial-interglacial cycle. Journal of Asian Earth Sciences 116. 132-138.

White, W.B. and Keester, K.L. 1966. Optical absorption spectra of iron in the rock-forming silicates. American Mineralogist 51. 774-791.

Wu, Y., Qıu, S., Fu, S., RAO, Z. and ZHu, Z. 2018. Pleistocene climate change inferred from multiproxy analyses of a loess-paleosol sequence in China. Journal of Asian Earth Sciences 154. 428-434.

Zeeden, C., Hambach, U., Veres, D., Fitzsimmons, K., Овreht, I., Bösken, J. and Lehmkuhl, F. 2018. Millennial scale climate oscillations recorded in the Lower Danube loess over the last glacial period. Palaeogeography, Palaeoclimatology, Palaeoecology 509. 164-181.

Zhang, Y.G., Ji, J.F., Balsam, W.L., LiU, L.W. and Chen, J. 2007. High resolution hematite and goethite records from ODP 1143, South China Sea: Co-evolution of monsoonal precipitation and El Niño over the past 600,000 years. Earth and Planetary Science Letters 264. 136-150.

Zhou, L.P. and ShackLETon, N.J. 1998. Loess spectrophotometry: A tool for detecting climate-related events. In Past Global Changes and Their Significance for the Future. PAGES Open Science Meeting, 20-23. April 1998. London, Poster abstracts. 
